\title{
Treatment of clay soils with steel slag, in road engineering.
}

\author{
Nizar Sebbar ${ }^{1 *}$, Abdelaziz Lahmili ${ }^{2}$, Lahcen Bahi $^{3}$, Latifa Ouadif $^{4}$ \\ ${ }^{1}$ nizarseb20@gmail.com, Ecole Mohammadia d'Ingénieurs, Université Mohammed V, Rabat, Maroc. \\ 21lahmili@emi.ac.ma, Ecole Mohammadia d'Ingénieurs, Université Mohammed V, Rabat, Maroc. \\ 3 bahi@emi.ac.ma, Ecole Mohammadia d'Ingénieurs, Université Mohammed V, Rabat, Maroc. \\ ${ }^{4}$ ouadif@emi.ac.ma, Ecole Mohammadia d'Ingénieurs, Université Mohammed V, Rabat.
}

\begin{abstract}
The road construction sector draws large quantities of materials every day to meet the needs of infrastructure networks. The main aim of the link between different regions is to facilitate the transport and connection of these agglomerations. With such a pace, a shortage of these materials is worsening by the day, causing an imbalance in our "ecosystem" on the way. All these factors and many others have raised the alarm among managers in the construction industry. Environmental organizations have since been constantly seeking palliative solutions to this global scourge. In addition, several industries generate a large amount of waste annually, in some cases recoverable while respecting certain technical and environmental criteria. It is in this environmental approach, embracing a philosophy of circular economy that multiple coproducts (Slag, Fly Ash, Phosphogypsum, Silica Fume...etc.) have been tested and numerous studies have demonstrated their ability to be used as a substitute for natural resources. In this respect, the following article will focus, through studies conducted in public laboratory, on various mixtures of the "soil-slag" couple to assess their possible use in road engineering. First, an identification of the materials (soil from the Sidi Kacem region and slags from a steel industry) to be adopted in our analysis will be carried out, then we will proceed to Proctor/CBR tests on soil-slag mixtures, defined in advance in order to decide on the possibility of developing them in road engineering and thereby reduce the quantities in contribution of noble materials.
\end{abstract}

\section{Introduction}

The construction sector requires the use of huge quantities of building materials. This has caused, over time, a shortage of natural resources whose impact on our ecosystem is worsening dayboy day. An alternative to this problem is urgently needed.

Through road managers, innovative and alternative solutions to natural resources have submerged on the surface of the construction and public works industry. Among these solutions are steel slags (steelmaking slag).

The latter are a co-product of steel manufacturing, through the melting of iron and scrap.

However, depending on the type of furnace, the composition of the additives added, as well as the refining process, different types of steelworks slag are obtained: Basic Oxygen Furnace (BOF), Electric Arc Furnace (EAF), Blast Furnace (BF)... etc.

At the beginning, these slags were considered as waste and stored in bulk, which was detrimental to the environment.

However, with the need for materials, we have begun to look at the possibility of their reuse in different fields (concrete, roads, cement, etc).

For our study, we will focus on their use in road sector.

\section{Applications of adding slag in road engineering}

The use of slag in road engineering dates back to the era of the Roman Empire, i.e. before 2000 years. The first slag road was built in England in 1813 [1]. And since 1880 , slag has been used as road pavement in Europe and the United States. However, with the increase in its production, it has proved important to find other uses for slag. However, even after demonstrating its cementitious properties (in contact with water), it was not until the early 20th century that the use of slag spread throughout the world [2].

Slags are named after the furnaces where they were generated. There are different types of slag, from the Iron and Steel industry. Steel mill slag includes blast furnace iron slag (Blast Furnace "BF"), oxygen furnace slag (Basic Oxygen Furnace "BOF") and electric arc furnace slag (Electric Arc Furnace "EAF") [3].

In each of these processes, the inputs (iron ore, scrap, fluxes such as lime and others) are introduced into a furnace and heated until the smelting process is reached.

Different liquids are formed when these materials reach a state of complete fusion. Since slags have the lowest density among this mixture of liquids, they rise to the surface.

\footnotetext{
*orresponding author: Tel: +212 676667913. nizarseb20@gmail.com
} 
During this process, substances incompatible with iron and steel are removed by forming metallic and nonmetallic complex oxides.

After removal from the furnace, the slag is transported to a pit for cooling. Before the slag is used, it is stored and dried for at least six months to reduce the free lime content and thus avoid having slag with poor performance.

The slag can then be crushed, graded and screened for multiple uses $[4,5]$.

The use of slag in several fields is mainly due to its mechanical characteristics, whether in the metallurgical or other industries [3].

Some examples of areas of use of slag are given [1]:

- Clinker production (as one of the raw materials),

- Use as aggregate in concrete and mortar [6, 7],

- Use in road construction (unbound base layer, stabilized cement base layer, soil improvement, etc),

- Fertilizers and liming products in agriculture.

In Morocco, most of the slag produced is generated in the Electric Arc Furnace (EAF). The process of manufacturing steel in an electric arc furnace can be summarized as follows: first, all types of scrap metal are loaded into the furnace, then electrodes are introduced into the furnace, creating an electric arc that through these electrodes and the metal will generate heat. Throughout this process, steel is formed at the bottom of the furnace and the slag, with a lower density, submerges on the surface of the liquid. Finally, the steel is poured into a ladle to be transported to a secondary steel production station for further refining $[5,6]$.

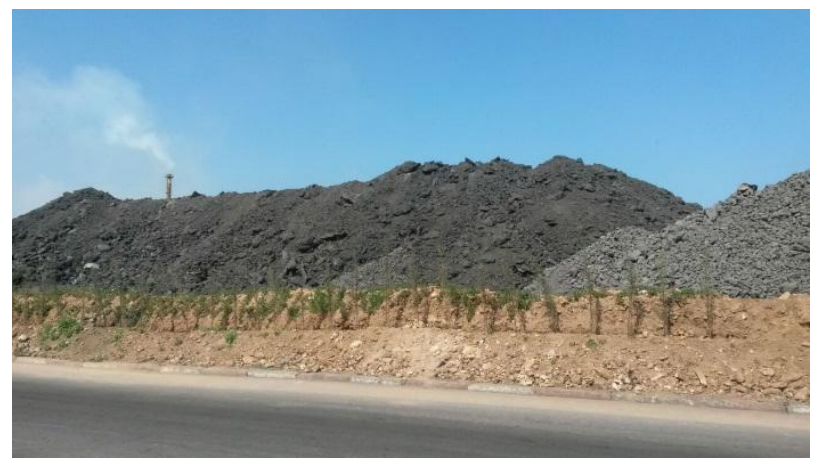

Fig.1.Stockpiled slags outdoors (Jorf Lasfar, Morocco)

Data on slag production in Morocco are not known, except for one steel company, whose annual production is around 100,000 tones.

A first experiment in the use of slag in road construction was carried out at the end of 2012 Fig. 2, in the El Jadida region. The two km long section connects Douar Lakouacem (commune Moulay Abdellah) to the RN1 national road. is:

The roadway structure adopted (in this experiment)

$$
15 \mathrm{~cm}(\text { Slags })+15 \mathrm{~cm}(\text { Slags })+\text { ES }^{\mathrm{i}}
$$

${ }^{\mathrm{i}}$ ES (Enduit Superficiel) : Sealed surface dressing

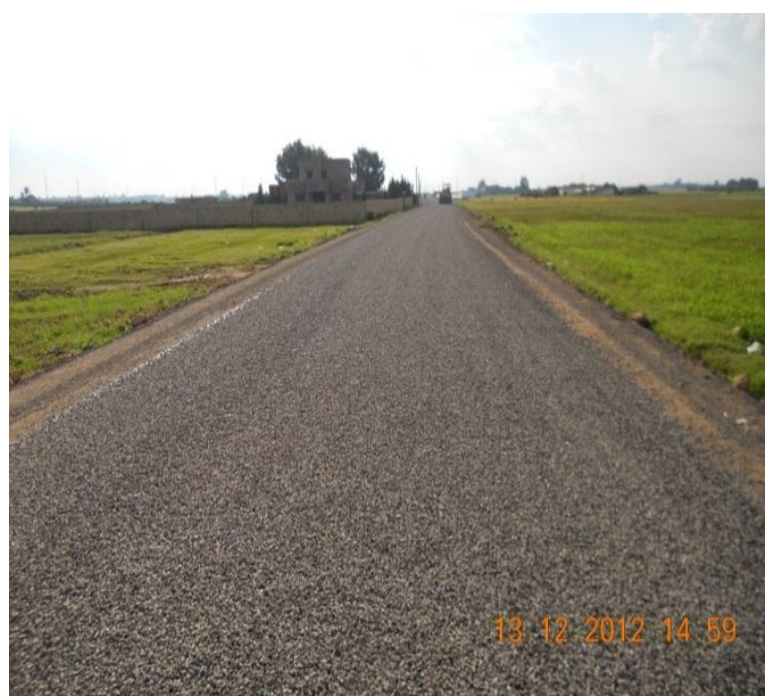

Fig.2.Photo of the section at the end of works

This experimental route was carried out by the company SONASID (a company that aims to be innovative in the field of sustainable development and circular economy), and followed by the National Centre for Road Studies and Research (CNER), as well as the Provincial Directorate of Equipment, Transport, Logistics and Water of El Jadida.

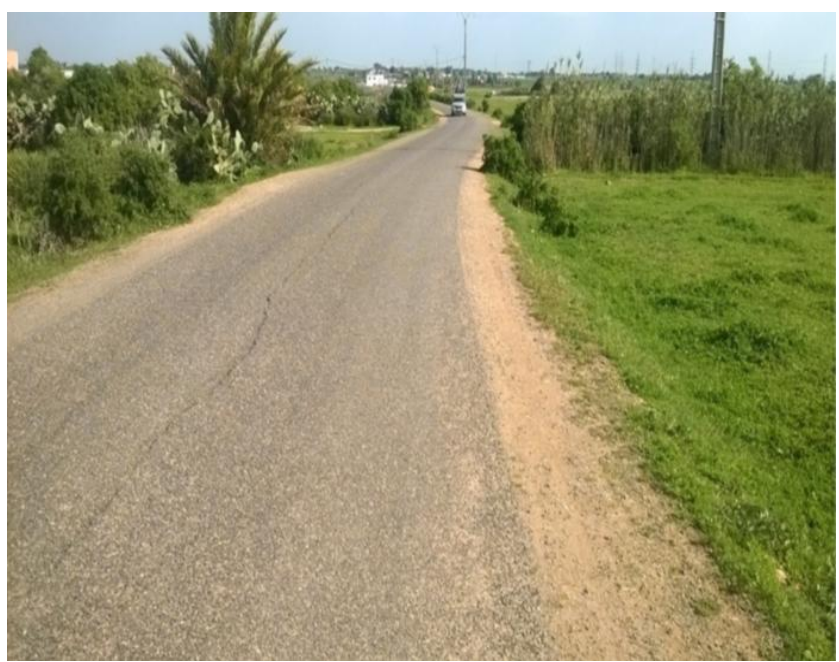

Fig.3.Photo of the section in 2016

The pavement inspection campaign carried out on the experimental section after completion of the work Fig. 3 showed good characteristics with regard to the road specifications.

One of the difficulties associated with the use of slag is its ability to increase volume.

Indeed, in contact with water, free calcium oxide or free magnesium oxide react with water and transform into calcium/magnesium hydroxides [1]. This reaction (and depending on the percentage of these elements) will cause the slag to swell, causing a loss of resistance as it passes.

Solutions to this problem include aging in the open air or immersion in water [8]. 


\section{Case study}

The soils of most of the Gharb are clayey, rather dark (grey/ black) with deep drying cracks in most cases. These soils, (often Tirs) are very present on the Gharb plain, sometimes with deep thicknesses. They are characterized by high volume instability, with strong cracking (shrinkage) in the dry season and high swelling in the wet state.

\subsection{Geographic context}

Located in northwest of Morocco, the Gharb region is bordered by the Tangier-Tetouan region to the north, the Atlantic Ocean to the west, the two regions of Taza Al Hoceima-Taounate and Fez-Boulemane in the east, and the regions of Meknes-Tafilalet and Rabat-SaléZemmour-Zaër regions in the South. The project is located in Sidi Kacem the region, it is characterized by its swelling soils and an average rainfall of $400 \mathrm{~mm} /$ year.

\subsection{Geological context}

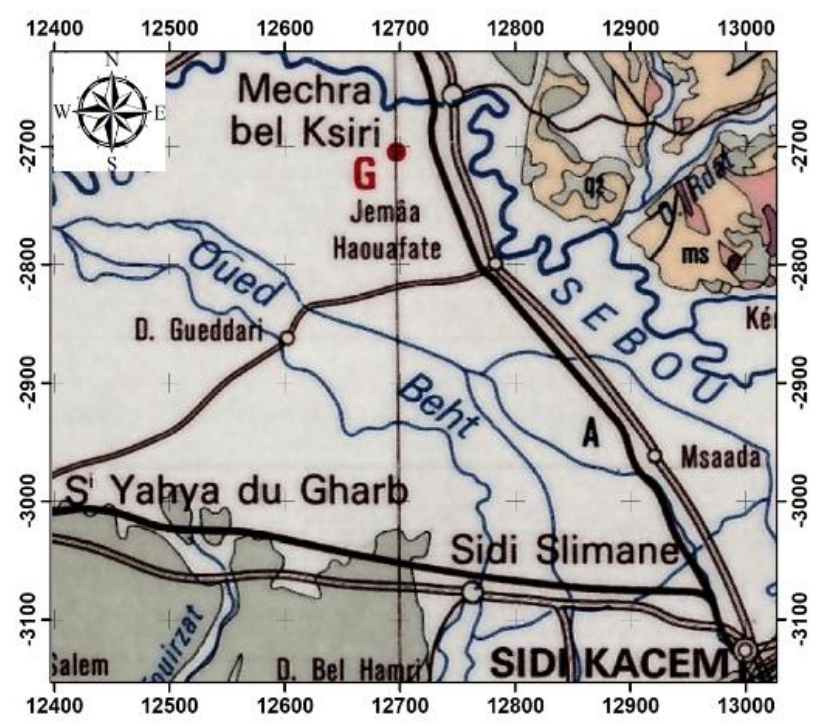

Legend :

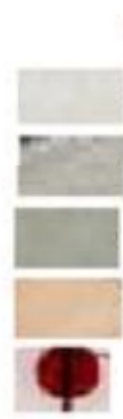

Quaternary and tertiary

Late Pleistocene and Holocene (A: Alluviums)

q2: Middle Pleistocene

q1 : Early Pleistocene "Villafranchian"

$\mathrm{m}_{\mathrm{s}}$ : Late Miocene

Mines and major mineralization (G: Gas)

Fig.4. Geological map of the Gharb region (study area)

The Gharb basin is characterized by a diversity of geological formations Fig.4, it is located at the junction of two major structural domains of Morocco: the Rifain domain (known by its two geological units, the Rifain chain in the north, and the Pre-Rif in the south), and the Mesetian domain belonging to the Hercynian chain marked by its subtabular Cenozoic cover consisting of flyschs and limestone marls.

The development of the Gharb basin is essentially due to the geological evolution of the previous structural domains during the Cenozoic period [9-11].

\section{Methodology}

\subsection{Soil of Sidi Kacem}

The soil on which this study is based comes from the Sidi Kacem region, specifically from the provincial road RP 4534. It is a grey floor, at first sight silt/clay type.

\subsection{Slags}

The slag used in our study comes from a factory in Jorf Lasfar, owned by a steel company. These are typical black slag, with a storage period of more than two years (according to information on site).

\subsection{LHR}

The LHR used is a hydraulic road binder for soil treatment and recycling of existing pavements. It allows the recovery of materials with characteristics that are unusable in their current state. LHR is a hydraulic road binder that complies with the Moroccan standard NM 10.1.015 [12] and European standard NF EN 13282 [13, $14]$, whose characteristics are as follows:

Table1: Characteristics of LHR

\begin{tabular}{|c|c|c|c|c|}
\hline $\begin{array}{c}\text { Apparent } \\
\text { density }\end{array}$ & $\begin{array}{c}\text { Retained } \\
\text { fraction } \\
\text { (sieve 90 } \\
\boldsymbol{\mu m} \text { ) }\end{array}$ & $\begin{array}{c}\text { Start time } \\
\text { of grip }\end{array}$ & $\begin{array}{c}\text { CS7 } \\
\text { days }\end{array}$ & $\begin{array}{c}\text { CS28 } \\
\text { days }\end{array}$ \\
\hline $1 \mathrm{t} / \mathrm{m}^{3}$ & $<15 \%$ & $>160 \mathrm{~min}$ & $\begin{array}{c}>14 \\
\mathrm{MPa}\end{array}$ & $\begin{array}{c}>32,5 \\
\mathrm{Mpa}\end{array}$ \\
\hline
\end{tabular}

\subsection{Methods}

Sampling is the preliminary step for any study. The quantities collected are placed in sealed bags to protect them from external contamination and then transported to CNER.

Once at the CNER, the samples are mixed and quartered so that homogeneous samples can be placed in the oven (at a temperature not exceeding $50^{\circ} \mathrm{C}$ ).

The tests carried out throughout this study were performed (in most cases) in the laboratory of the CNER (Centre National des Etudes et Recherches Routières). However, the chemical tests were carried out in external laboratories. These tests focused first on the identification of the materials used. Secondly, tests were carried out on the Soil-Slag/ Soil-LHR pairs, as well as a characterization of the black slags used in our study. 
The identification of the materials covered the following tests: particle size analysis (NM EN 9331:2018), Plasticity Index (NF P94-051:1993), Methylene Blue Test (NM EN 933-9:2018), Sand Equivalent (NM 10.1.147:1995), the Sand Equivalent at 10\% fines (NM 10.1.732:2009), the Los Angeles Test (NM EN 10972:2018), the Micro Deval Test (NM EN 1097-1:2018), the Proctor Test (NF P94-093:2014), and the CBR Test (EN 13286-47:2012).

Concerning the characterization of black slag leachate used in this study, the analysis was carried out by a flame atomic absorption spectrometer. For Selenium and Arsenic, the hydride system was used.

\section{Results and discussion}

\subsection{Identification tests}

The physical, chemical and mechanical properties performed on the study materials are summarized in the following table:

Table 2: Physical and mechanical properties of the soil

\begin{tabular}{|c|c|}
\hline Test & Result \\
\hline Particles $\geq 50 \mathrm{~mm}$ & 0 \\
\hline Particles $\leq 63 \mathrm{~mm}$ & $98 \%$ \\
\hline Liquid Limit & 54 \\
\hline Plastic Limit & 31 \\
\hline Plasticity Index & 23 \\
\hline Methylene blue value (VBS) & 5 \\
\hline Optimum moisture content (W ${ }_{\text {opn }}$ ) & 20.6 \\
\hline Maximum dry density & 1,61 \\
\hline Immediate bearing index (IPI) & 3,4 \\
\hline CBR $_{4 J}$ Index (4days) & 2 \\
\hline
\end{tabular}

From on the results obtained (Table 2), we can see that the soil, the object of the study, is of Class A2 according to the GMTR classification [15].

Compared to the $\mathrm{CBR}_{4 \mathrm{~J}}$ test results, the value obtained (relative to the optimal water content Fig.5) gives us a bearing capacity class $\mathrm{St} 0\left(\mathrm{CBR}_{4 \mathrm{~J}}\right)$, a poor bearing capacity class, requiring the addition of new, more noble materials, or the use of soil treatment solutions.

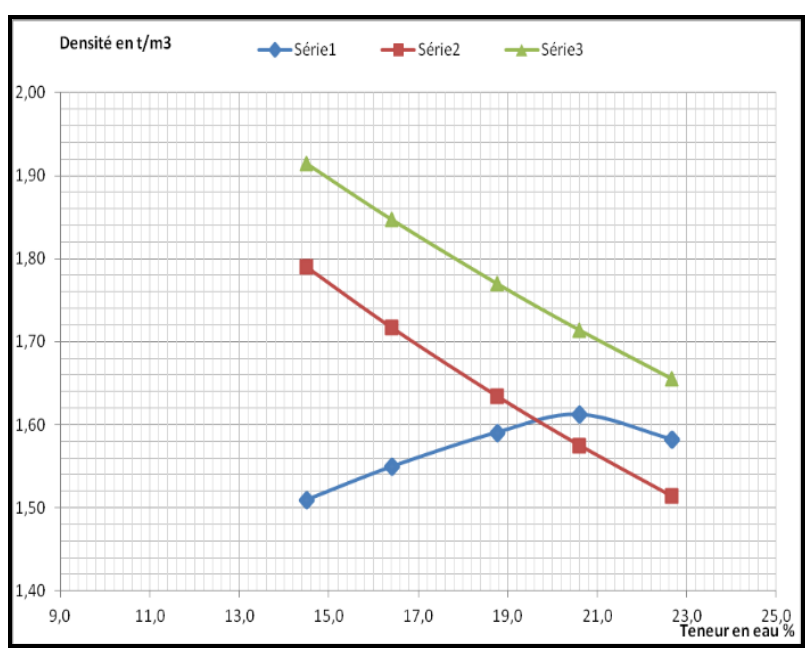

Fig.5. Normal PROCTOR curve (soil without addition)

\subsection{Tests on slag}

An identification of the slags (materials to be added to the soil in our study) remains important, in order to optimize the solution to be adopted, in case of favorable results of one of the formulations.

\subsubsection{Identification tests}

Table 3: Physical and mechanical properties of slag

\begin{tabular}{|c|c|c|}
\hline Test & \multicolumn{2}{|c|}{ Result } \\
\hline Particles $\geq 50 \mathrm{~mm}(\%)$ & \multicolumn{2}{|c|}{0} \\
\hline Particles $\leq 63 \mathrm{~mm}(\%)$ & \multicolumn{2}{|c|}{3,3} \\
\hline Plasticity Index (\%) & \multicolumn{2}{|c|}{ Unmeasurable } \\
\hline \multirow[b]{2}{*}{ Methylene blue value $(\mathrm{g} / \mathrm{kg})$} & MB & 0,75 \\
\hline & $\mathrm{MB} 0 / \mathrm{D}$ & 0,14 \\
\hline Sand Equivalent (\%) & \multicolumn{2}{|c|}{74} \\
\hline Sand Equivalent $10 \%$ of fines $(\%)$ & \multicolumn{2}{|c|}{61} \\
\hline Los Angeles (\%) & \multicolumn{2}{|c|}{21} \\
\hline MDE (\%) & \multicolumn{2}{|c|}{9} \\
\hline Optimum moisture content (\%) & \multicolumn{2}{|c|}{3,7} \\
\hline $\mathrm{CBR}_{4 \mathrm{~J}}$ (4days) & \multicolumn{2}{|c|}{62,7} \\
\hline Swelling (4days ; 15days) & \multicolumn{2}{|c|}{$(0 ; 0)$} \\
\hline
\end{tabular}

From Table 3, we can see that slag has good mechanical characteristics, giving it the possibility to be used instead of certain untreated gravel (GNT) in the pavement body, provided that the grain size spindle is corrected. The CBR swelling (at 4 and 15 days) is nil, offering sufficient stabilization of the slag.

\subsubsection{Leachate tests}

Through Table 4, the values obtained from the various analyses show that the slag leachate collected from this site and used in this study (except for $\mathrm{pH}$ ), complied 
with the General Limit Values for Discharges into Surface and Ground Water (VLGRD) according to Order No. 3826-17 of 4 September 2017.

Table 4: Leachate analysis results for black slag

\begin{tabular}{|c|c|c|}
\hline Parameters & Results & VLGRD \\
\hline $\mathrm{pH}$ & 10,28 & $5,5-9,5$ \\
\hline Barium $(\mathrm{Ba}) \mathrm{mg} / \mathrm{l}$ & 0,196 & 1 \\
\hline $\operatorname{Tin}(\mathrm{Sn}) \mathrm{mg} / \mathrm{l}$ & $<0,2$ & 2,5 \\
\hline Chromium (Cr) mg/l & $<0,005$ & 2 \\
\hline Aluminium $(\mathrm{Al}) \mathrm{mg} / \mathrm{l}$ & 0,10 & 10 \\
\hline Zinc $(\mathrm{Zn}) \mathrm{mg} / \mathrm{l}$ & $<0,003$ & 5 \\
\hline Manganese (Mn) mg/l & 0,006 & 2 \\
\hline Molybdenum (Mo) mg/l & $<0,02$ & --- \\
\hline Nickel (Ni) mg/l & $<0,008$ & 5 \\
\hline Iron $(\mathrm{Fe}) \mathrm{mg} / \mathrm{l}$ & $<0,004$ & 5 \\
\hline Copper $(\mathrm{Cu}) \mathrm{mg} / \mathrm{l}$ & $<0,005$ & 2 \\
\hline Cadmium (Cd) $\mathrm{mg} / \mathrm{l}$ & $<0,003$ & 0,25 \\
\hline Lead $(\mathrm{Pb}) \mathrm{mg} / \mathrm{l}$ & $<0,01$ & 1 \\
\hline Selenium $(\mathrm{Se}) \mathrm{mg} / \mathrm{l}$ & $<0,00015$ & 0,1 \\
\hline Arsenic (As) mg/l & $<0,00005$ & 0,1 \\
\hline
\end{tabular}

\subsection{Soil / slag tests}

After identifying the materials used, we opted for 2 formulas of the Soil-Slag couple, with $10 \%$ and $20 \%$ (internal percentage in the mixture) in slags of $(0 / 2 \mathrm{~mm})$. We will focus mainly on the Proctor, IPI and $\mathrm{CBR}_{4 \mathrm{~J}}$ tests (at 4 days after immersion). The results of the tests performed are summarized in Table 5.

Table 5: Results of test on soil/slag couple

\begin{tabular}{|c|c|c|}
\hline Test & Soil/Slag10\% & Soil/Slag20\% \\
\hline Optimum moisture content & 18,6 & 18,4 \\
\hline Maximum dry density & 1,65 & 1,68 \\
\hline $\begin{array}{c}\text { Immediate bearing index } \\
(\mathrm{IPI})\end{array}$ & 2,7 & 6,7 \\
\hline $\mathrm{CBR}_{4 \mathrm{~J}}$ Index & 16,2 & 16,9 \\
\hline
\end{tabular}

It can be seen that the optimal moisture content has decreased, and the maximum dry density has increased, with the addition of slag as a percentage (Fig.6 and Fig.7).

This also has an effect on the values (IPI and $\mathrm{CBR}_{4 \mathrm{~J}}$ ), since the addition of slag fines to the soil increased these values from 3.2 to 6.7 (for IPI), and from 2 to 16.9 (for $\mathrm{CBR}_{4 \mathrm{~J}}$ ), with a percentage of $20 \%$ slag.

The change from $10 \%$ slag to $20 \%$ slag did not significantly affect the $\mathrm{CBR}_{4 \mathrm{~J}}$ values.

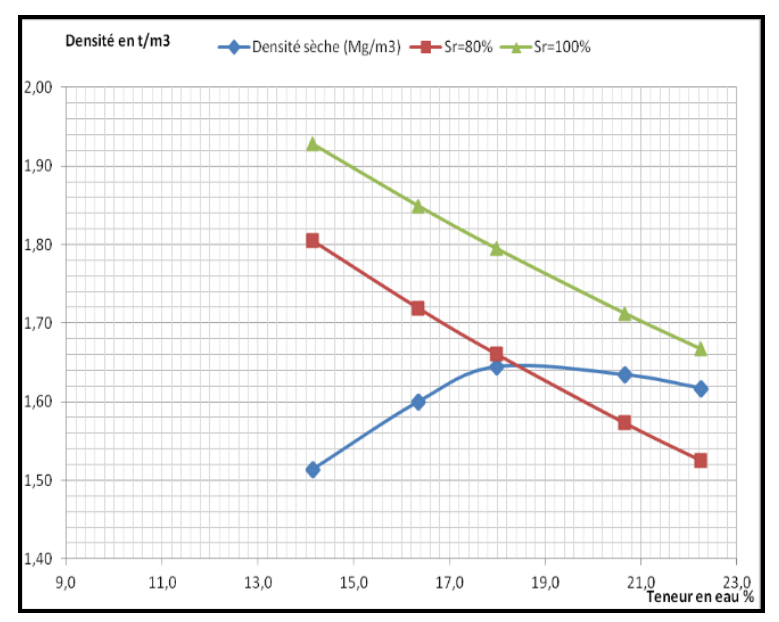

Fig.6.Normal PROCTOR curve (soil/slag 10\%)

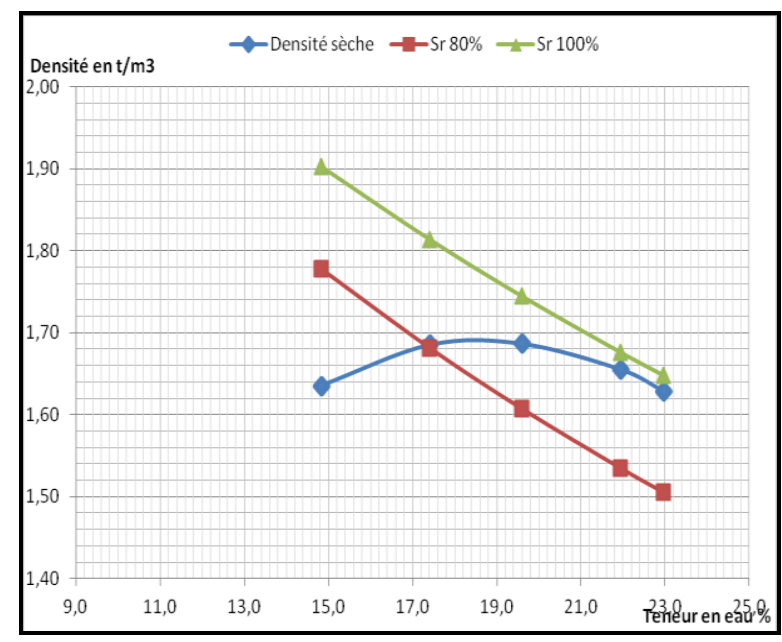

Fig.7. Normal PROCTOR curve (soil/slag 20\%)

\subsection{Soil/LHR tests}

Another formulation was made, this time with the addition of the LHR (5\%).

The objective being to make a comparison with the results obtained from the 2 previous formulations with slag, in order to continue this study with other formulations.

The results of the first tests carried out in the CNER laboratory, are summarized in Table 6.

Table 6: Proctor/ CBR test results (with the addition of LHR)

\begin{tabular}{|c|c|}
\hline Test & Result \\
\hline Optimum moisture content & 18 \\
\hline Immediate bearing index (IPI) & 15,5 \\
\hline $\mathrm{CBR}_{4 \mathrm{~J}}$ Index & 62,3 \\
\hline
\end{tabular}

After the addition of 5\% LHR to the soil, there was a significant improvement in the IPI $(15,5)$ and $\mathrm{CBR}_{4 \mathrm{~J}}$, from 2 (without addition) to 62 (with LHR). 
Table 7: comparison between the different formulations

\begin{tabular}{|c|c|c|c|}
\hline Test & IPI & $\mathbf{C B R}_{\mathbf{4 J}}$ & $\mathbf{C B R}_{\mathbf{4 J}}$ /IPI \\
\hline Soil/slag0\% & 3,4 & 2 & 0,59 \\
\hline Soil/slag10\% & 2,7 & 16,2 & 6 \\
\hline Soil/slag20\% & 6,7 & 16,9 & 2,52 \\
\hline Soil/LHR5\% & 15,5 & 62,3 & 4,02 \\
\hline
\end{tabular}

From Table 7 , it can be seen that the $\mathrm{CBR}_{4 \mathrm{~J}} / \mathrm{IPI}>1$ condition is valid for all formulas (except for soil without addition). In view of these results, the use of soil/slag couple in backfill can be accepted.

However, since the condition of $\mathrm{CBR}_{4 \mathrm{~J}}>20$ is not satisfied for soil/slag pairs, they are not allowed as material for subgrade [16].

\section{Conclusions}

Road construction remains one of the most resourceintensive activities, generating huge amounts of greenhouse gas (GHG) emissions and damaging our ecosystem.

One of the alternatives to this scourge is none other than the recovery of materials by various products (lime [17], LHR, fly ash, enzymes...).

As we have seen, the addition of slag fines in different percentages has increased the bearing capacity of the soil, while reducing the quantities of soil to be used.

Knowing that slag is a secondary natural resource, with less GHG emissions impact than quarry soil and its use will reduce $\mathrm{CO}_{2}$ emissions, the gain would not only be economic but also environmental.

\section{References}

1. N. Grubeša, I., Barišić, I., Fucic, A., \& Bansode, S. $\mathrm{S}$. Applications of steel slag in civil engineering. Characteristics and Uses of Steel Slag in Building Construction, 67-82 (2016).

2. 3rd European Slag Conference: Proceedings Manufacturing and Processing of Iron and Steel Slags, EUROSLAG Publication, Keyworth, UK, pp. 7-20 2002,

3. H. Yi, G. Xu, H. Cheng, J. Wang, Y. Wan, \&H. Chen. An Overview of Utilization of Steel Slag. Procedia Environmental Sciences, 16, 791-801 (2012).

4. J. Guo, Y. Bao, \&M. Wang. Steel slag in China: Treatment, recycling, and management. Waste Management, 78, 318-330 (2018).

5. C. Thomas, J. Rosales, J. A. Polanco, \&F. Agrela. Steel slags. New Trends in Eco-Efficient and Recycled Concrete, 169-190 (2019).
6. V. Ducman, \& A. Mladenovič. The potential use of steel slag in refractory concrete. Materials Characterization, 62(7), 716-723 (2011).

7. L. Chunlin, Z. Kunpeng, \&C. Depeng. Possibility of Concrete Prepared with Steel Slag as Fine and Coarse Aggregates: A Preliminary Study. Procedia Engineering, 24, 412-416 (2011).

8. H. Motz, J. Geiseler. Products of steel slags: an opportunity to save natural resources. Waste Management, 21(3), 285-293 (2001).

9. A. MICHARD, Eléments de la géologie marocaine. Notes et Mémoires, Service Géologique du Maroc, $\mathrm{n}^{\circ}$ 252, 420 (1976)

10. M. Combe, Bassin du Rharb Maâmora. In ressources en eau du Maroc. Tome2.Notes et Mem, Serv, Geol, Maroc, 231, 93 e128 (1975)

11. M. El Bouhaddioui, A. Mridekh, M. Kili, B. El Mansouri, El H. EL Gasmi, B. Magrane. Electrical and well $\log$ study of the Plio-Quaternary deposits of the southern part of the Rharg Basin, northern Morocco. Journal of African Earth Sciences (2016).

12. IMANOR NM 10.1.015: Liants hydrauliques routiers Composition, spécifications et critères de conformité (2018).

13. AFNOR NF EN 13282-1: Liants hydrauliques routiers - Partie 1 : liants hydrauliques routiers à durcissement rapide - Composition, spécifications et critères de conformité (2014).

14. AFNOR NF EN 13282-2: Liants hydrauliques routiers - Partie 2 : liants hydrauliques routiers à durcissement normal - Composition, spécifications et critères de conformité (2015).

15. Direction des routes et de la circulation routière \& Laboratoire Public d'Essais et d'Etudes (Morocco) : Guide marocain pour les terrassements routiers « GMTR » (2002).

16. Guide technique SETRA-LCPC. Traitement des sols à la chaux et/ou aux liants hydrauliques- Application à la réalisation des remblais et des couches de forme (GTS). (janvier 2000).

17. Sebbar, Nizar \& Lahmili, A \& Latifa, Ouadif \& Akhssas, A \& Bahi, Lahcen. (2018). Soil treatment in flood areas: case of the road RP4209, in the province of Kenitra (Morocco). MATEC Web of Conferences. 149. 02029. (2017).

18. https://www.euroslag.com/products/statistics/statisti $\underline{\text { cs-2016/ }}$

19. http://www.nationalslag.org/slag-history

20. https://www.worldsteel.org/en/dam/jcr:2941f748b906-4952-8b11-03ffee835b39/Coproducts_position_paper_vfinal.pdf 